\title{
Implementasi Metode Tutor Sebaya Dalam Meningkatkan Partisipasi Belajar Ipa Siswa Kelas Vi Sd Muhammadiyah Aimas Kabupaten Sorong
}

\author{
Hairul Malik, A.Ma.Pd \\ SD Muhammadiyah Aimas Kabupaten Sorong
}

\begin{abstract}
Students got direct experiences through taking participation so that learning process become meaningful. Meanwhile, the participation of VI grade students at SD Muhammadiyah Aimas Sorong Regency on the subject of Science (IPA) was still low. This research aimed at improving students' learning participation through peer tutor in the Science Subject on IV grade students at SD Muhammadiyah Aimas Sorong Regency. Students participations were contributive and initiative participations. This research was classroom action research with the subject IV grade students at SD Muhammadiyah Aimas Sorong Regency which consisted of 24 students. This research was conducted in two cycles that every cycle consisted of four steps, those were planning, action, observation and reflection. The techniques of collecting data used were observation and test. The data was analyzed descriptive quantitative and qualitative. The result showed that there was improvement on students' learning participation on the Science Subject of IV grade at SD Muhammadiyah Aimas through peer tutor. The participation average was $84,26 \%$ and improved $21,30 \%$ from the previous cycle. It could be seen from the students' participation from pre-action until cycle II which each of them were 48,96\% and 62,96\% with the improving score was $14 \%$.

Keywords: peer tutor, learning participation, Science Subject (IPA), Sd muhammadiyah Aimas
\end{abstract}

Abstrak: Siswa memperoleh pengalaman-pengalaman secara langsung dengan berpartisipasi sehingga pembelajaran menjadi bermakna. Sementara itu, partisipasi belajar siswa kelas VI SD Muhammadiyah Aimas Kabupaten Sorong pada mata pelajaran IPA masih rendah. Penelitian ini bertujuan untuk meningkatkan partisipasi belajar siswa melalui metode tutor sebaya dalam mata pelajaran IPA siswa kelas VI SD Muhammadiyah Aimas Kabupaten Sorong. Partisipasi belajar siswa berupa partisipasi kontributif maupun inisiatif. Penelitian ini merupakan jenis Penelitian Tindakan Kelas dengan subjek siswa kelas VI SD Muhammadiyah Aimas Kabupaten Sorong yang berjumlah 24 siswa. Penelitian ini dilaksanakan dalam dua siklus masing-masing siklus terdiri dari empat tahapan yaitu perencanaan, tindakan, observasi, dan refleksi. Teknik pengumpulan data menggunakan observasi dan tes. Data dianalisis secara deskriptif kuantitatif dan kualitatif. Hasil penelitian menunjukkan bahwa terjadi peningkatan partisipasi belajar dalam pembelajaran IPA siswa kelas VI SD Muhammadiyah Aimas Kabupaten Sorong melalui metode tutor sebaya. Rata-rata partisipasi belajar yang diperoleh sebesar $84,26 \%$ dengan peningkatan $21,30 \%$ dari siklus sebelumnya. Hal tersebut dapat dilihat dari rata-rata partisipasi belajar siswa dari sebelum tindakan sampai siklus II secara berturut-turut 48,96\% dan 62,96\% dengan peningkatan sebesar $14 \%$.

Kata kunci: metode tutor sebaya, partisipasi belajar, IPA, SD Muhammadiyah Aimas 


\section{Pendahuluan}

Pendidikan sekolah dasar merupakan pondasi awal untuk jenjang pendidikan selanjutnya dan merupakan pengenalan pada anak untuk kehidupan di masyarakat. Pendidikan sekolah dasar dituntut untuk menyiapkan siswa menjadi siswa yang unggul dalam pengetahuan, sikap, dan keterampilan. Keterampilan yang berkaitan dengan pemecahan masalah menjadi penting sebagai bekal bagi siswa untuk dapat hidup mandiri di lingkungan masyarakat serta membantu mereka dalam menyelesaikan masalah yang berkaitan dengan kehidupan sehari-hari.

Untuk itu dalam proses pembelajaran, sekolah harus terus meningkatkan kemampuan siswa dalam tiap mata pelajaran seperti IPA, IPS, Bahasa Indonesia, PKn, Matematika, dan mata pelajaran yang lain agar dapat memberikan bekal kepada semua siswa menjadi manusia unggul.IPA sebagai salah satu mata pelajaran di sekolah dasar dinilai memiliki peranan penting karena dapat meningkatkan pengetahuannya dalam berpikir secara logis, rasional, kritis, cermat, efektif, dan efisien.

Oleh karena itu, pengetahuan IPA harus dikuasai sedini mungkin oleh para siswa dalam menghadapi perubahan keadaan di dalam kehidupan dan dunia yang selalu berkembang.IPA merupakan salah satu mata pelajaran pokok dalam kurikulum (KTSP) tahun 2006 di sekolah dasar. Mata pelajaran ini diajarkan mulai dari kelas awal 1, 2, dan 3 melalui model pembelajaran Tematik sampai kelas tinggi yaitu 4, 5, dan 6 melalui pembelajaran yang disajikan secara utuh.

Materi-materi IPA memiliki keterkaitan erat dengan kejadian-kejadian, fakta, teori-teori yang berhubungan dengan alam dan sekitarnya. Sementara itu, KTSP sebagai pembaharuan KBK menghendaki bahwa pembelajaran pada dasarnya tidak hanya mempelajari tentang konsep, teori, dan fakta tetapi juga aplikasi dalam kehidupan seharihari. Oleh karena itu, penyampaian materi IPA membutuhkan pendekatan-pendekatan, metode, strategi serta teknik pembelajaran yang tepat serta tidak menimbulkan kesan bahwa materi IPA merupakan materi yang penuh hafalan.Komarudin (Trianto, 2009: 8) menyatakan bahwa perubahan paradigma pembelajaran dalam KTSP adalah orientasi pembelajaran yang semula berpusat pada guru (teacher centered) beralih berpusat pada siswa (student centered); metodologi yang semula lebih didominasi ekspositori berganti ke partisipatori; dan pendekatan yang semula lebih banyak bersifat tekstual berubah menjadi kontekstual. Perubahan-perubahan tersebut untuk memperbaiki mutu pendidikan baik dari segi proses maupun hasil pendidikan. 
Dari uraian permasalahan di atas, maka peneliti tertarik untuk melakukan penelitian tindakan kelas di kelas VI SD Muhammadiyah Aimas Kabupaten Sorong untuk meneliti apakah melalui metode tutor sebaya dapat meningkatkan partisipasi belajar IPA pada kelas VI SD Muhammadiyah Aimas Kabupaten Sorong.

\section{Metode Penelitian}

\subsection{Desain Penelitian}

Penelitian ini merupakan jenis penelitian tindakan kelas atau action research. Wina Sanjaya (2011: 26) mengatakan bahwa penelitian tindakan kelas dapat diartikan sebagai proses pengkajian masalah pembelajaran di dalam kelas melalui refleksi diri dalam upaya untuk memecahkan masalah tersebut dengan cara melakukan berbagai tindakan yang terencana dalam situasi nyata serta menganalisis setiap pengaruh dari perlakuan tersebut.

Penelitian ini menggunakan model spiral dari Kemmis dan Taggart yang dikembangkan oleh Stephen Kemmis dan Robin Taggart. Model yang dikemukakan oleh Kemis dan Mc Taggart berupa perangkat-perangkat atau untaian-untaian dengan satu perangkat terdiri dari empat komponen, yaitu: perencanaan, tindakan, pengamatan dan refleksi.

\subsection{Subjek Penelitian}

Subjek dalam penelitian ini adalah siswa kelas VI SD Muhammadiyah Aimas Kabupaten Sorong dengan jumlah 24 siswa.

\subsection{Lokasi dan Waktu Penelitian}

Penelitian dilakukan di SD Muhammadiyah Aimas Kabupaten Sorong yang beralamat di . penelitian dilaksanakan mulai bulan Agustus 2015 hingga Oktober 2015.

\subsection{Teknik Pengumpulan Data}

Dalam penelitian ini metode pengumpulan data yang digunakan adalah observasi dan tes.

1) Observasi : Observasi dalam penelitian ini digunakan untuk memperoleh data tentang partisipasi siswa maupun aktivitas guru dalam kegiatan pembelajaran. Pelaksanaan observasi dalam penelitian ini dilaksanakan oleh peneliti dengan dibantu pengamat lain di setiap pertemuan.

2) Tes : Tes dalam penelitian ini digunakan untuk memperoleh hasil tentang kemampuan kognitif siswa. Tes dilaksanakan disetiap akhir siklus. Adapun bentuk tes yang digunakan adalah berbentuk soal isian singkat. 


\subsection{Teknik Analisis Data}

Peneliti menganalisis data kualitatif melalui lembar observasi siswa serta data kuantitatif melalui tes hasil belajar.

1) Analisis Data Observasi

a. Analisis Data Observasi Siswa

Data hasil observasi akan dianalisis secara deskriptif kualitatif dengan indikator tingkat partisipasi atau keaktifan siswa dalam proses pembelajaran. Persentase partisipasi belajar siswa diperoleh dengan teknik analisis data yang yang diolah dengan rumus :

Keterangan :

$$
\boldsymbol{P}=\frac{F}{N} \mathrm{x} 100 \%
$$

$$
\begin{aligned}
& \mathrm{P}=\text { Angka persentase siswa. } \\
& \mathrm{F}=\text { Frekwensi aktivitas siswa. } \\
& \mathrm{N}=\text { Jumlah siswa. }
\end{aligned}
$$

Kriteria partisipasi siswa ditentukan dengan memperhatikan pedoman konversi tingkat aktivitas siswa menurut Suharsimi Arikunto (2009: 156).

b. Analisis Data Observasi Guru

Analisis instrumen lembar observasi aktivitas guru dalam mengelolapembelajaran ditentukan oleh laporan dari hasil pengamatan yangdilakukan pengamat pada tiap pertemuan. Hasil laporan ini digunakanuntuk merefleksi pembelajaran pada siklus berikutnya.

\section{2) Analisis Tes}

Hasil tes yang diperoleh dari siswa dianalisis secara deskriptif kuantitatif untuk mengetahui seberapa besar peningkatan hasil kognitif IPA pada siswa kelas VI dibuktikan dengan hasil tes evaluasi yang dilaksanakan setiap siklus. Peningkatan hasil belajar siswa pada pembelajaran IPA yang dilakukan peneliti, dapat diketahui dengan menghitung persentase ketuntasan belajar berdasarkan KKM di SD Negeri Kaligesing yaitu sebesar 70. Ketuntasan hasil belajar dihitung dengan menggunakan rumus :

$$
\text { Ketuntasan }(\%)=\frac{\mathrm{R}}{\mathrm{JS}} \times 100 \%
$$

Keterangan : 
$\mathrm{R}=$ Jumlah siswa yang mendapat nilai $\geq 70$.

JS = Jumlah seluruh siswa (Ngalim Purwanto, 2004: 102).

Penelitian dikatakan berhasil apabila peningkatan partisipasi belajar siswa mencapai $>80 \%$. Dengan arti kata partisipasi belajar siswa berhasil bila mencapai persentase sangat baik sehingga siklus dapat dihentikan.

\section{Hasil Penelitian Dan Pembahasan}

\subsection{Hasil Penelitian}

1) Siklus I

Hasil observasi tingkat partisipasi belajar siswa pada siklus I sudah mengalami peningkatan dibandingkan pra tindakan, yaitu pada pra tindakan hasil observasi rata-rata tingkat parisipasi hanya mencapai $48,96 \%$. Pada siklus I, rata-rata tingkat partisipasi belajar IPA mengalami peningkatan sebesar $14 \%$ menjadi 62,96\%. Pada siklus I kriteria keberhasilan penelitian belum mampu terpenuhi, karena rata-rata tingkat partisipasi siswa baru mencapai 62,96\%. Oleh karena itu, penelitian tindakan kelas ini perlu dilanjutkan pada siklus II.

Berdasarkan hasil pengamatan, hasil evaluasi dan hasil diskusi dengan guru, ada beberapa hal penting yang dapat direfleksikan ke dalam tindakan selanjutnya agar pelaksanaan proses pembelajaran IPA dengan menggunakan metode tutor sebaya di kelas VI SD Muhammadiyah Aimas Kabupaten Sorong dapat lebih meningkatkan kualitas pembelajaran. Pada siklus I, masih terdapat siswa yang menyebabkan kegaduhan. Hal tersebut diatasi dengan cara tutor mengkondisikan siswa yang bersenda gurau saat proses pembelajaran berlangsung. Cara yang digunakan tutor untuk mengkondisikan siswa yang ribut sendiri adalah dengan mencatat anggotanya yang ramai. Tidak hanya itu, siswa yang tidak mengerjakan tugas dari guru juga dicatat dan akan mengurangi nilai kelompok.

\section{2) Siklus II}

Secara umum dalam pelaksanaan siklus II ini tidak ditemukan kendala yang berarti, karena pelaksanaan siklus II ini merupakan perbaikan dari saran-saran yang dikemukakan pada Siklus I serta hasil diskusi dengan guru. Guru bersama peneliti menerapkan cara yang lebih efektif yaitu tutor selain membimbing anggotanya mengerjakan LKS juga bertugas mengkondisikan anggotanya. Hal demikian tentu saja berdampak pada partisipasi belajar siswa.Partisipasi yang terus mengalami peningkatan dari setiap tindakan sampai pada siklus II. Pada kondisi awal hasil observasi proses 
pembelajaran hanya mencapai $48,96 \%$, pada siklus I mengalami peningkatan menjadi $62,96 \%$ dan pada siklus II juga mengalami peningkatan menjadi $84,26 \%$.

\subsection{Pembahasan}

Sri Sulistyorini (2007: 39) mengatakan bahwa IPA berhubungan dengan cara mencari tahu tentang alam secara sistematis, sehingga IPA bukan hanya penguasaan kumpulan sistematis dan IPA bukan hanya penguasaan kumpulan pengetahuan yang berupa fakta-fakta, konsep-konsep atau prinsip-prinsip saja, tetapi juga merupakan suatu proses penemuan. Oleh karena itu, karakteristik pembelajaran IPA sendiri lebih menekankan pada membangun atau mengkonstruksi pengetahuan tentang konsep yang dibahas. Proses ini memerlukan interaksi siswa dengan sumber belajar. Oleh karena itu, metode pembelajaran yang akan digunakan perlu juga memperhatikan karakteristik siswanya. Hal yang paling mendasar, yang dituntut dalam proses pembelajaran adalah partisipasi/keaktifan siswa. Partisipasi/keaktifan siswa dalam proses pembelajaran akan menyebabkan interaksi yang tinggi, antara guru dengan siswa ataupun dengan siswa itu sendiri. Sehingga suasana kelas menjadi aktif dan kondusif, karena siswa dapat melibatkan kemampuannya semaksimal mungkin.

Dussel Dorp (Sukidin dkk, 2007: 159) menyatakan bahwa partisipasi merupakan suatu kegiatan atau keadaan mengambil bagian dalam satu aplikasi dalam suatu aktivitas untuk mencapai kemanfaatan secara optimal. Melalui aktivitas dan partisipasi siswa dalam pembelajaran, siswa memperoleh pengalaman-pengalaman secara langsung sehingga pembelajaran menjadi bermakna. Siswa yang berpartisipasi dalam belajar akan mudah menangkap dan memahami isi dari materi pembelajaran yang disampaikan oleh guru sehingga dapat memacu prestasi belajar siswa menjadi lebih baik.

Metode Tutor Sebaya adalah proses pembelajaran partisipasi dalam kelompok. H. Abu Ahmadi dan Widodo Supriyono (2003: 45) mengatakan bahwa tutor adalah siswa yang sebaya yang ditunjuk/ditugaskan membantu temannya yang mengalami kesulitan belajar, karena hubungan antara teman umumnya lebih dekat dibandingkan hubungan guru-siswa. Dengan petunjuk-petunjuk dari guru tutor ini membantu temannya yang mengalami kesulitan. Pemilihan tutor ini didasarkan atas prestasi, punya hubungan sosial baik dan cukup disenangi oleh temantemannya. Tutor berperan sebagi pemimpin dalam kegiatan kelompok sebagai pengganti guru.

Teori perkembangan Piaget memperkuat pendapat di atas yakni perkembangan kognitif sebagian besar ditentukan oleh manipulasi dan interaksi aktif anak dengan lingkungan. Pengetahuan datang dari tindakan. Piaget yakin bahwa pengalaman- 
pengalaman fisik dan manipulasi lingkungan penting bagi terjadinya perubahan perkembangan. Sementara itu, interaksi sosial dengan teman sebaya, khususnya beragumentasi dan berdiskusi membantu memperjelas pemikiran yang pada akhirnya memuat pemikiran itu lebih logis (Nur dalam Trianto, 2009: 29).

Pada kondisi awal pembelajaran IPA, guru menggunakan metode ceramah, karena metode tersebut merupakan metode yang umum digunakan guru kelas VI dalam pembelajaran IPA. Saat pembelajaran berlangsung sebagian besar siswa tidak terlalu aktif, baik itu aktif dalam mengajukan pendapat atau pertanyaan, aktif menjawab pertanyaan, maupun aktif dalam kegiatan diskusi. Oleh karena itu, tingkat partisipasi belajar siswa masih rendah. Pada kondisi awal guru belum memberikan tindakan yaitu dengan menggunakan metode tutor sebaya.

Pada siklus I guru telah menerapkan tindakan berupa pembelajaran IPA dengan menggunakan metode tutor sebaya pada materi ciri-ciri khusus makhluk hidup. Tindakan pada siklus I sudah sesuai dengan materi dan sudah menggunakan metode yang sesuai yaitu metode tutor sebaya. Hal itu terbukti bahwa partisipasi belajar siswa pada pembelajaran IPA pada siklus I lebih tinggi dibandingkan partisipasi pada saat pra tindakan. Dengan demikian dapat dikatakan bahwa penggunaan metode tutor sebaya dapat meningkatkan partisipasi belajar IPA siswa karena dengan menggunakan metode tutor sebaya siswa menjadi lebih aktif.

Pada siklus II masih terdapat beberapa aspek yang belum mencapai > 80\% diantaranya aspek mengajukan pendapat, mengajukan tanggapan, dan inisiatif mempelajari materi yang belum dan akan diajarkan. Hal tersebut karena beberapa siswa masih merasa takut salah. Namun, mengingat penelitian di SD Muhammadiyah Aimas Kabupaten Sorong ini menerapkan kriteria keberhasilan penelitian yaitu terjadi peningkatan rata-rata partisipasi belajar siswa sebesar $>80 \%$, sedangkan pada siklus II diperoleh persentase mencapai $84,26 \%$ maka penelitian tindakan kelas ini dikatakan berhasil.

Berdasarkan data siklus I maupun siklus II dapat dinyatakan bahwa penggunaan metode tutor sebaya dapat meningkatkan partisipasi belajar IPA siswa kelas VI pada pokok bahasan ciri khusus makhuk hidup.Kenaikan partisipasi belajar siswa juga diikuti oleh kenaikan nilai hasil evaluasi siswa pada siklus I dan II. Pada siklus I, rata-rata kelas adalah 69 dengan persentase ketuntasan 45,83\% atau sebanyak 11 siswa telah mencapai angka ketuntasan belajar. Sementara pada siklus II, rata-rata kelas menjadi 73 dengan 
persentase ketuntasan $75 \%$ atau sebanyak 18 siswa telah mencapai angka ketuntasan belajar.

\section{Kesimpulan Dan Saran}

\subsection{Kesimpulan}

Berdasarkan hasil penelitian dan pembahasan, dapat disimpulkan bahwa penggunaan metode tutor sebaya dapat meningkatkan partisipasi belajar IPA pada pokok bahasan ciri khusus makhluk hidup siswa SD Muhammadiyah Aimas Kabupaten Sorong. Sebelum dikenakan tindakan diperoleh rata-rata tingkat partisipasi siswa 48,96\%. Pada siklus I diperoleh tingkat partisipasi belajar siswa mengalami kenaikan sebesar $14 \%$ menjadi $62,96 \%$. Partisipasi siswa meningkat setelah modifikasi tindakan pada siklus II. Modifikasi tindakan yang dilakukan yaitu tutor bertugas mengkondisikan anggotanya agar tetap fokus dengan pekerjaannya. Partisipasi belajar siswa pada pembelajaran IPA lebih tinggi dibandingkan pada siklus I yaitu mengalami kenaikan sebesar 21,30\% menjadi $84,26 \%$.

\subsection{Saran}

Memperhatikan dari kesimpulan di atas, dapat dikemukakan beberapa saran antara lain:Bagi Kepala Sekolah, Kepala Sekolah perlu mendukung guru untuk menggunakan metode tutor sebaya dalam pembelajaran IPA dengan memfasilitasi maupun memberikan pelatihan pada guru.Bagi Guru, Guru sebaiknya mengimplementasikan metode tutor sebaya dalam pembelajaran IPA selain metodemetode yang lain agar siswa lebih aktif sehingga pembelajaran menjadi bermakna.

\section{Daftar Pustaka}

Ahmadi, Abu dan Widodo Supriyono. 2004. Psikologi Belajar. Jakarta: Rineka Cipta. Anggoro, M. Toha, dkk. 2007. Metode Penelitian. Jakarta: Universitas Terbuka. Arikunto, Suharsimi. 2006. Prosedur Penelitian Sebagai Suatu Pendekatan Praktik. Jakarta: Bumi Aksara. .2009. Penelitian Tindakan Kelas. Jakarta: Bumi Aksara.

Asy'ari, Maslichah. 2006. Penerapan Pendekatan Sains - Teknologi-Masyarakat dalam Pembelajaran Sains di SD. Yogyakarta: Universitas Sanata Dharma.

B, Suryo Subroto. 2002. Proses Belajar Mengajar di Sekolah. Jakarta: Rineka Cipta.

Bundu, Patta. 2006. Penilaian Keterampilan Proses dan Sikap Ilmiah dalam Pembelajaran Sains SD. Jakarta: Depdiknas Dirjen Dikti.

Dimyati dan Mudjiono. 2006. Belajar dan Pembelajaran. Jakarta: Rineka Cipta.

Djamarah, Syaiful Bachri dan Aswan Zain. 2010. Strategi Belajar Mengajar. Jakarta: Rineka Cipta.

Hamzah, B. Uno. 2009. Model Pembelajaran. Jakarta: Bumi Aksara. 
Kusumah, Wijaya dan Dedi Dwitagama. 2012. Mengenal Penelitian Tindakan Kelas. Jakarta: PT Indeks.

Mulyasa, E. 2007. Kurikulum Tingkat Satuan Pendidikan. Bandung: Remaja Rosdyakarya.

Mulyono. 2011. Strategi Pembelajaran Menuju Efektivitas Pembelajaran di Abad Global. Malang: UIN-Maliki Press.

Samatowa, Usman. 2006. Bagaimana Membelajarkan IPA di Sekolah Dasar. Jakarta: Departemen Pendidikan Nasional.

Sanjaya, Wina. 2011. Penelitian Tindakan Kelas. Jakarta: Prenada Media Group.

Silberman, Melvin L. 2006. Active Learning 101 Cara Belajar Siswa Aktif. Bandung: Nusa Media dan Nuansa.

Slameto. 2003. Belajar dan Faktor-Faktor yang Mempengaruhinya. Jakarta: Rineka Cipta.

Sukidin, dkk. 2007. Manajemen Penelitian Tindakan Kelas. Surabaya: Insan Cendekia.

Sulistyarini, Sri. 2007. Pembelajaran IPA Sekolah Dasar dan Penerapannya dalam KTSP. Yogyakarta: Kiara Wacana.

Suparno, Paul. 2004. Guru Demokratis di Era Reformasi. Jakarta: Gramedia Widiasarana Indonesia.

Taniredja, Tukiran, Irma Pujiati dan Nyata. 2010. Penelitian Tindakan Kelas. Bandung: Alfabeta.

Trianto. 2009. Mendesain Model Pembelajaran Inovatif Progresif. Jakarta: Kencana Prenada Media Group. 